\title{
Corporate Sustainability Reporting Performance in Vietnam and Indonesia in Banking Sector: Social Disclosure and Its Relation to Corporate Governance
}

\author{
Nguyen Thi Kim OANH ${ }^{1 *}$, Nguyen Van DINH ${ }^{1}$, Tran Thi Minh ANH ${ }^{1}$ \\ ${ }^{1}$ Vietnam National University, Hanoi - International School \\ *Corresponding author: nguyenthikimoanh@,vnu.edu.vn
}

\begin{abstract}
Purposes: This study attempts to evaluate corporate sustainability reporting performance of banks in Vietnam and Indonesia based on a framework developed by Global Sustainability Standard Board, namely General Reporting Initiatives $G 4$ and its relation to corporate governance.
\end{abstract}

Research motivation: Prior studies found out that corporate governance significantly affects CSRE performance. Therefore, it is important to identify corporate governance configuration leading to high CSRE performance.

Research design, approach and method: First, a systematic scoring method was employed to evaluate CSR performance of 13 listed banks in Vietnam and 12 Islamic banks in Indonesia from 2014 to 2018. Secondly, relationships between corporate sustainability reporting performance and corporate governance are investigated by employing Qualitative Comparative Analysis (QCA). The uniqueness of QCA compared to other quantitative methods is that this method focusing on configuration of factors affecting CSRE performance rather than the extent to which each individual factor affecting CSRE performance.

Main findings: The first findings of the study show ranking on CSRE performance of banks in Vietnam and Indonesia from 2014 to 2018. In addition, the results report improvement and deterioration of the banks.

Concerning the effects of corporate governance on CSRE performance, the study finds three configurations or three causal paths that lead to high CSRE performance in Vietnam and Indonesia. In Indonesia, two configurations highlights the presence of board independence and large Board of Director (BOD) size as two important corporate governance variables resulting in high CSRE performance of Islamic banks. In Vietnam, listed banks achieve high CSRE performance only when seven corporate governance variables, namely large BOD size, board independence, female chairman, BOD nationality diversity, $B O D$ gender diversity, firm age and external audit reputation, are presented.

Implications: The study on ranking, improvement or deterioration of CSRE performance of banks in Vietnam and Indonesia benefit banks themselves. Firstly, the research findings enable banks in Vietnam and Indonesia to make further enhancement in CSRE performance. Secondly, the banks can focus on certain corporate governance variables to ensure their high performance on CSRE. Last but not least, the results provide investors and other stakeholder's additional information to make more informed decisions related banks, especially when banks are listed on the Stock Exchange.

Keywords: Corporate social responsibility, Corporate sustainability reporting GRI-G4, banking sectors, Vietnam, Indonesia. 


\section{INTRODUCTION}

Corporate social responsibility (CSR) has been concerning by businesses globally regarding various aspects of firm performance such as economics, environment, and social issues. As such, the firms focus on CSR principles to support strategic decisions effectively (Abdul Rashid and Ibrahim, 2002; Collier and Wanderley, 2005; Jamali and Mishak, 2007; Kathe Newman and Santoro, 2014). There are several frameworks provide guidelines on CSR disclosure such as GRI, ASSET4, or AA1000. Among these frameworks, GRI-G4, the most updated framework, outperform other frameworks in terms of a set of indicators to measure the firm's CSR performance and clear guidelines on how to prepare the CSRE (Islam and Chowdhury, 2017).

Prior studies attempt to evaluate CSR performance in developed countries (e.g. the United State, the United Kingdom, Spain, or Australia) in various sectors such as logistics manufacture (e.g. Patten, 2002; Frost et al., 2005; Nasrin Asgari et al., 2015; IdilKaya, 2016; Minelle E.Silva and D.Figueiredo, 2020). Nasrin Asgari et al. (2015) evaluated sustainability performance on economic and environmental dimensions of five major UK ports while IdilKaya (2016) assessed social and environment dimensions to reflect sustainable operations of French companies. Minelle E.Silva and D.Figueiredo (2020) contributes to understanding how a medium manufacturing organization and its supply chain practice sustainability in Brazil. Despite popularity of CSR practices in developed countries, organizations in developing countries have started to be aware of these practices (Daizy et al., 2013). For instance, ThomasBorgert et al. (2020) evaluated corporate sustainability of foreign multinational manufacturing enterprises in Indonesia. Dissanayake et al. (2016a) used a content analysis to measure the environmental disclosures on CSRE of banking sectors in Bangladesh based on CRI guidelines.

Factors associated with CSRE performance has been investigated and the previous findings indicate that corporate governance is one of the most important factor (e.g. Khan, 2010b; Giannarakis, 2014; Kilic, 2015; Dienes, 2016). Haslinda Yusoff and Zunaidah Ahman (2019) find that the larger the board size, the more companies are accountable to disclose CSR information while numerous studies show that the relationship between CSR disclosure and board independence is positive, because independent directors have the ability to engage in motivating firm to show information related to CSR activities (Lattemann, 2009; Khan et al., 2013a). Moreover, Dienes and Velte find that the number of women in the board has a positive significant relationship with CSRE (Dienes, 2016). Similarly, Zhang (2013) found that high CSR performance are associated with a greater presence of women on the BoD. Muller (2014) find that the portion of foreign directors has substantial and strong positive impacts on firm performance. Firm age and external audit reputation might also have some effects on CSRE performance. Therefore, it would be more useful to know which corporate governance configuration might lead to high CSRE performance.

In order to identify which corporate governance configuration leads to high CSRE performance, Qualitative Comparative Analysis (QCA) is employed. The uniqueness of QCA compared to other quantitative methods lies is that this method focus on configuration of factors affecting CSRE performance rather than the extent to which each individual factors have effects on CSRE performance (Ragin, 1987).

The banking sector was selected due to its vital role in the economy (Ogrizek, 2002). In Vietnam, banks have seriously taken CSR into considerations when facing more intensive competition. However, studies concerning CSRE performance are limited in the context of developing countries like Vietnam (Peter Dobers and Halme, 2009; Hoang Thi Mai Khanh and Tuan, 2018). Therefore, this study aims to evaluate CSRE performance of banking sectors in Vietnam in comparisons with that in Indonesia and understand corporate governance configuration resulting in high CSRE performance.

Banks in Vietnam and Indonesia were purposely selected because these two countries have similar economic conditions. Moreover, listed region banks in Indonesia has the same structure system as commercial banks in Vietnam. Being different from banks in Vietnam, Indonesian banks are known as Islamic banking,non-interest banking. This banking system is based on principles of Islamic or Sharia law and guided by Islamic economics (Komijani and Taghizadeh-Hesary, 2018). Islamic banks make a profit through equity participation, which requires a borrower to give the bank a share in their profits rather than paying interest. Islamic banks have the same purpose as conventional banking except that it operates in accordance with the governing conceptual framework of Islamic Banking (Sangmi and Khaki, 2018). As such, this study attempts to evaluate CSRE performance of banks two developing countries: Vietnam and Indonesia. This provides more balance for studies on CSRE performance in developed and developing countries(Peter Dobers and Halme, 2009). Moreover, this study attempts to understand corporate governance configuration resulting in high CSRE performance

\section{LITERATRURE REVIEW AND HYPOTHESES}

\subsection{Corporate Social Responsibility (CSR)}

Although the term CSR has been differently defining in the literature, CSR usually refers to organizational commitment to contributing to sustainable economic development and improve employees' life, taking responsibility for the impacts of their actions on the community and environment legally and ethically in a specific business context (Frederick W, 1992; Carroll, 1999; Petkoski, 2003). 
In the recent years, CSR have started to report because due to its benefits (Bonsón, 2015). Firstly, CSR helps organizations to enhance its reputation, improve financial performance, reduce the risk and achieve higher earnings. (Bonsón, 2015). Secondly, CSR can improve competitive advantage of organizations and give them an additional opportunity for success (Porter, 2006). Thirdly, non-financial information on CSRE provide further details in to organizational operations, which supports stakeholders to make informed decision making (Kinder, 1997).

\subsection{Corporate Sustainability Reporting (CSRE)}

\subsubsection{Definition of CSRE}

Global Reporting Initiative (GRI) defined sustainability report as a report published by organizations to disclose information related to environmental, social and economic aspects of firm performance. This CSRE can be called as non-financial reporting, triple bottom-line reporting, corporate social responsibility reporting (GRI, 2013).

\subsubsection{CSR and CSRE practices}

In recent years, a growing number of organizations discloses CSR performance via their CSRE (Bartels et al., 2016). The CSRE has been practicing by more than 600 enterprises in 65 countries of which six countries, namely Australia, Brazil, China, India, South Africa and the USA, had the highest number of organizations participating in CSRE practices. The rate of businesses practicing CSRE varied across continents: $45 \%$ in business in Europe, $18 \%$ in Asia, 14\% in North America, $14 \%$ in Latin America, and 5\% in Africa. About 142 legal regulations for Sustainable Development have been issued in more than 30 countries, of which $65 \%$ set CSRE as a mandatory report for organizations such as "KING CODE III" in South Africa or "Guidance" in China (VBCFSD, 2014).

Companies are increasingly viewing sustainability as a necessity in achieving their business objectives and becoming more responsible for their impacts on environment, social issues and economics created over the value chains (Snow, 2019). In 2011, just under 20 percent of S\&P 500 companies reported on their sustainability, corporate social responsibility, and related topics (Mitchell, 2019). By 2019, the number of S\&P 500 companies practice the CSRE rose to 86 percent.

\subsection{The CSRE frameworks: GRI-G4}

Over the past 10 years, there are various frameworks providing guidelines for CSRE practices such as "UN Global Compact Principles, OECD Guidelines for Multinational Enterprises, GRI, ISO 26000, AA1000, ISO 14001 and SA88000" (Marimon, 2012). Among them, Global Reporting Initiative (GRI) has been considered the world's most popular framework for reporting sustainability performance and shows the advantages over the other frameworks (Lamprinidi, 2008; Brown, 2009). Firstly, GRI focuses on guiding company how to disclose its information and data to demonstrate sustainable development and social responsibility rather than general standards as in case of AA1000 Series and UN Global Compact Principles. Secondly, the GRI-G4 Guidelines encourage companies to measures CSR outcomes rather than verifying sustainability performance through processes (GRI, 2013a).

The GRI committee delivered the first set of sustainability reporting guidelines in June 2000. The latest version of GRI, called GRI-G4 released in 2013, which is more user-friendly and accessible. GRI-G4 contains of specific indicators on three categories of economic, environmental and social aspects. The Social Category of GRI-G4 is divided into four sub-categories, namely Labor Practices and Decent Work, Human Rights, Society, and Product Responsibility, which is the main focus of this study.

\subsection{Social aspects in banking sector in developing countries}

In GRI-G4, Social Category consists of 48 social indicator on employment, labor, management relationships, occupational health/safety, education and training, diversity/equal opportunities, non-discrimination, freedom of association/right to join unions and collective bargaining, child labor, forced or compulsory labor, security practices, indigenous rights, assessment human rights, local communities, social supplier assessments, public policy, customer health and safety, marketing and trademark, customer information security rights, and business compliance social-economic. The company must report both external and internal activities. For the former, the firm needs to report indicators measuring its performance on human rights aspects, fair competition, and gender equality, or employee welfare policies, are elements of internal responsibility. Besides, the company need to disclose and encourage anti-corruption policies, anti-competitive and monopolistic practices that can harm the stakeholders, or providing labeling products for the health and safety of customers (Aisyah, 2017).

CSRE practices have emerged in developing countries such as Vietnam and Indonesia. In Vietnam, a survey conducted by the State Bank of Vietnam in early 2019 released 76 percent of participating banks has had sustainable finance strategies in place. It is an evidence shows that Vietnamese banks have further concern about CSR. As such, the banks are encouraged to adopt international CSRE practices, which might be included in their annual reports (VBCFSD, 2014).

In Indonesia, the Islamic banking system, also known as the interest-free banking system, is a system based on the principles of Islamic law. It is governed by ideologies in Islamic economics. The two basic principles of the Islamic banking system are profit or loss sharing and no interest or interest free (Hussain M, 2015). Due to direct relevance and significance of CSR with explicit and implied teachings of Islam, CSRE has become a major concern of scholars in the area of Islamic banking 
(Dusuki AW, 2007). Theoretically, the literature in the context of Islamic banking show that Islamic rules is far beyond the conventional CSR principles (Dusuki AW, 2008). However, others argue a contradiction between ideology and reality of social responsibility of Islamic banking (Kamla R, 2013). These disagreements build an interest to investigate CSRE practices of Islamic banking in comparisons with non-Islamic banking like Vietnam.

\subsection{Corporate governance and CSRE performance}

Corporate governance refers to the way a corporation is governed, which facilitates companies to exercise better ethical practices, especially when companies are facing increasing stakeholder pressure related to disclose sustainable information (Chen and \& Wang, 2011; Fernandez-Feijoo, 2012b). They expect companies to disclose not only financial but also non-financial information (Jensen, 1979; Hill and \& Jones, 1992; Fernandez-Feijoo, 2012b). Agency theory Jensen and Meckling (1976) and stakeholder theory Freeman (1984) have been two predominant perspectives used to explain the relationship between corporate governance and CSR Agency theory explains the conflicting relationship between managers and stakeholders supposing that existence of information asymmetry, opportunistic behavior of agents, and disputes of interests between principal (shareholder) and agent (manager). Therefore, it is necessary to monitor the agents closely so as to align the principal - agent goals, decrease conflicts and maximize the wealth of stockholders (Halme and Huse, 1997). Agency theory states that effective corporate governance improves firm's capability to contend with emerging challenges and reduce the agency conflicts (Haniffa and Cooke, 2002). In addition, it maintains that the internal governance mechanism must act effectively to hold manager accountable for their actions (Kolk, 2008; Li et al., 2008; Buniamin et al., 2011; Ienciu et al., 2012). The agency literature suggests that effective corporate governance can improve a firm legitimacy (Michelon and Parbonetti, 2012) and enhance financial performance (Rose et al., 2011).

Although the agency theory has been used to identify the relation of $\mathrm{CG}$ and CSRE, this framework seems unable to fully explain the link between corporate governance and CSR (Nazim Hussain et al., 2018). Hence, stakeholder theory offers complement to agency theory in explain this relationship. (Fodio and \& Oba, 2012; Mallin, 2013; Amran et al., 2014). One theory independent of the other cannot completely clarify why and how social targets should be included in corporate strategic goals (Walls et al., 2012)

Stakeholder theory provides concerning factors of decision-making in organizations, which is based on ethical and moral principles (UKEssays, 2018). By acting in an ethical manner to ensure greater fairness in the consideration of different stakeholders, the organization can create trust relationships which results in long-term profit. Moreover, taking care different stakeholders can reduce and prevent them potentially damaging the business. The organization is likely to benefit overall when corporate responsibility is considered in the decision-making process. Therefore, it is difficult to separate the concepts of corporate responsibility and its strategy. Under stakeholder theory, Michelon and Parbonetti (2012) also argue that good corporate governance enhances firm-stakeholder relationships by promoting corporate sustainability. Good governance and sustainability are considered as complementary mechanisms for better stakeholder management.

Prior studies suggest links between corporate governance and CSRE performance (Khan, 2010b; Nielsen, 2010; Hafsi, 2013; Giannarakis, 2014; Kilic, 2015; Dienes, 2016). This study focuses on seven corporate governance variables, namely Board of Directors Size, Board of Independence, Chairman Female, Board of Director National Diversity, Board of Directors Gender Diversity, Firm age, External Audit Reputation.

\subsubsection{Board of Director Size}

Board of director is an important part of governance bodies that serve important functions for organizations, ranging from monitoring management on behalf of different shareholders to providing resources (Guido Corbetta, 2004). Members of this group do not work in the company on a daily but they have right to hire and retire these managers to control enterprise's operations to gain profits for their firms. Some previous studies identified that BOD size is one of potential factors which are influential and dominant to CSRE. According to Haslinda Yusoff and Zunaidah Ahman (2019) finds the result that the larger the board size, the more companies are accountable to disclose CSR information. Similarly, Rekha Pillai and Al-Malkawi (2017) reveals that the BOD emerged as a vital determinant of firm performance with both the performance measures in all the GCC (Lipton and Lorsch, 1992; Kiel. C.G. and Nicholson.J.G., 2003; Leblanc and Gillies, 2003). This implies that a large board size is detrimental to the firm performance of companies and the firms ought to limit their board size ranging 8-11. Thus, BOD size would be expected to impact CSRE performance.

\subsubsection{Board independence}

An independent director refers to a member of a board of directors who does not have a material relationship with a company or enjoy personal interests in the company. This person is neither part of its executive team nor involved in the daily operations of company. Some experts argued that independent directors create higher level of monitoring of the management and provide better the board's effectiveness (Rosenstein, 1990; Michelon, 2012). They are not only responsible to shareholders but also ensure the benefit of other stakeholders (Ibrahim, 1995). Therefore, many studies have shown that the relationship between CSR disclosure and board independence is positive because independent directors have the ability to engage in 
motivating firm to show information related to CSR activities (Lattemann, 2009; Khan et al., 2013a). The results of these studies identify that a higher proportion of independent directors increases the focus on CSR disclosure (Barako, 2008; Khan, 2010a). However, other studies report no relationship between independent directors and CSR reporting (Said, 2009; Michelon, 2012). Even according to the report of Haniffa (2005), independent directors have negative impacts on the CSR disclosure. These results of previous studies are controversial. As such, the relationship between CSR reporting and board independence will continue to be examined.

\subsubsection{Female chairman}

In the recent years with the trend of gender equality, it is not strange for women to hold an important position in a company or organization. Many people believe that women holding the top position will influence the strategy and all operations of the company (Adams, 2009). Female directors are likely to positively effect on the management activities by using their skills and knowledge on legal, communication, and public relations more than their male counterparts (Zelechowski, 2004). Therefore, female directors are one of the commonly analyzed factors when evaluating the relationship between corporate governance and CSR disclosure. The results of previous studies show the disagreement about the relationship between CSR reporting and female directors. Dienes (2016) found that the number of women in the board has a positive significant relationship with CSRD. However, Haslinda Yusoff (2019) found the opposite result. That is, female directors in the board is insignificant and negatively related to the accountability related CSRE. This study focuses impact of female chairman on CSRE performance.

\subsubsection{BOD National Diversity}

The board of director nationality diversity is one of the most important elements of the corporate governance mechanism in overseeing the effective and appropriate operation of the company. Directors who come from different countries could bring different perspectives on whether the crucial corporate goal is to maximize shareholders' interests or broader stakeholders' interests. These differences could determine the vision of firms' objectives to exist in our society and their social performance. There are several studies focused on the impact of foreign directors on firm value and corporate social responsibility and generally found a positive impact. Naciti (2019b) found that the foreign directors are attentive to share-holders' interest and can be more in tune with relational sustainability strategies. Also, the portion of foreign directors has substantial and strong positive impacts on firm performance (Muller, 2014). However, Janggu (2014) found that foreign directors do not have a significant influence on sustainability disclosure. This paper will further examine the relationship between BOD nationality diversity and CSRE performance.

\subsubsection{BOD gender diversity}

As the definitive authority within a company, the board plays an essential role in shaping the firm's vision, maximizing and ensuring the interests and benefits of shareholders. Historically, most all boards of directors predominantly comprised of male directors. However, in recent years, there is a strong argument that board members do those jobs better when they include women. Most existing studies have found that a positive relationship between women in the boardroom and firm performance. The research investigated that board diversity is positively associated with firm performance (Erhardt, 2003; Hutchinson, 2015). Another series of practical studies indicate that the presence of women on a BOD is expected to be positively associated with CSR performance. Zhang (2013) found that high CSR performances are associated with a greater presence of women on BOD. Besides, companies with a higher number of female gender directors have a higher quality of CSR reporting and a higher incidence of assurance reports accompanying such disclosure (Fernandez-Feijoo, 2012a). However, Rose (2007) does not find a momentous association between female directors and firm performance of listed firms in Denmark. Therefore, in this result, we will examine the relationship between BOD gender diversity and CSRE.

\subsubsection{Firm age}

Firm age seen as the number of years that bank listed in stock exchange, generally matters for the actual CSR implementation. Some prior research has examined the association between the CSR disclosure and firm age listed on Stock Exchange and finds a significant association. Correa-Garcia et al. (2020) found that firm maturity, understood as the firm age in years from its creation, also impacts positively on sustainability reporting quality, which evidences the learning curved that firm acquire over the years for improving voluntary disclosures. This will examine the relationship between firm age and CSRE performance.

\subsubsection{External audit reputation}

External audit reputation refers to auditing companies being employed by the banks to audit their financial statements by big four auditing companies. The big four auditing firms include KPMG, Deloitte, PricewaterhouseCoopers and Earnest \& Young. Detthamrong et al. (2017) claims that firms which have financial statements audited by well-known auditors would likely reduce information asymmetry and signals financial markets about the firm's prospects. In addition, better audit quality is expected to improve the firm's decision-making process and the resulting operation. Therefore, we expect the relationship between audit reputation and CSRE to be positive. 


\section{RESEARCH METHODS}

In order to investigate CSRE performance and its relation to corporate governance, we employ two research methods: qualitative content analysis and qualitative comparative analysis (QCA). The former was used to evaluate CSRE performance of Vietnamese banks and Indonesian Bank while the later was adopted to investigate configuration of corporate governance leading to high performance on CSRE.

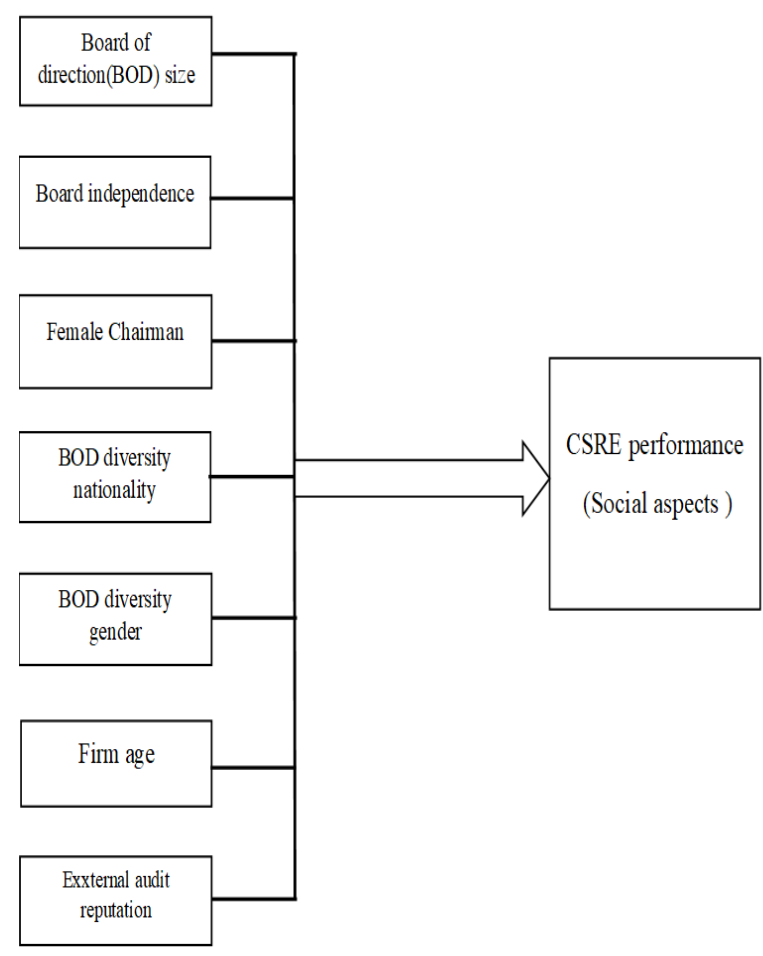

Fig. 2.1: Research framework

(Source: Author, 2021)

\subsection{Sample and data collection}

Twenty-five banks in Vietnam and Indonesia were purposely selected because these two countries have similar economic conditions. In Vietnam, 13 listed banks in Vietnam were chosen: 03 banks listed on Hanoi Exchange Stock (HNX) and 10 banks listed on Ho Chi Minh Stock Exchange (HOSE). In Indonesia, we selected 12 regional Islamic banks managed by Indonesia local government rather than private banks owned by foreign investors (all private banks in Indonesia are owned by foreign investors).

We collected data from 125 published annual reports of 25 banks in Vietnam and Indonesia from 2014 to 2018. In Vietnam, HDB bank was not released annual report of 2014. In Indonesia, Jambi bank was not published annual report of 2016. Also, six annual reports in English (version) were not released in Indonesia. They are annual reports in 2014 of DKI, Riau Kepri and
Sulselbar banks; annual reports in 2015 of Nagari and Kalbar banks; annual report in 2018 of Kalsel bank. Thus, data were collected from 117 instead of 125 annual reports.

\subsection{Measurement}

\subsubsection{Measurement of CSRE performance}

\subsubsection{Scoring method as qualitative content analysis}

Content analysis is defined by Krippendorff (1980) as systematic procedures for studying the content of written documents. This is a technique of gathering data that consists of codifying qualitative information in anecdotal and literary form, into categories in order to derive quantitative scales of varying level (Abbott and Monsen, 1979).

Scoring method was applied to convert texts from annual report into numeric index in order to maintain and ensure the quality and fairness of disclosure. This method has been widely implemented in CSRE research and considered as an appropriate method to assess quality of sustainability reporting (Clarkson et al., 2008; Dissanayake et al., 2016b; Islam and Chowdhury, 2017; Khanh, 2018).

\subsubsection{Scoring procedure}

Step 1: Read annual reports of the banks and identify statement related to social pillar of the GRI-G4 framework.

Step 2: Match statements in annual reports to social indicators of the GRI-G4 framework. For example, the statement " $100 \%$ of Sacombank's operations are examined risk factors related to corruption" related to the item of indicator GA- SO3 in the GRI-G4 that requires companies to report "total number and percentage of operations assessed for risks related to corruption and the significant risks identified."

Step 3: Scoring each GRI-G4 indicator of the social pillar for every annual report between 2014 and 2018 based on disclosure requirement of the GRI-G4. A fully disclosed indicator had a score of $100 \%$. The score of each item was calculated by the following formula:

Item score $=$ Indicator score/ a number of items

$=100 \% /$ a number of items

Each item was given a certain score based on extent to which each item was disclosed: a score of $100 \%, 50 \%$ and $0 \%$ was respectively given to fully disclosed, partly disclosed and not disclosed.

For example, the indicator G4-LA9 has only one item, thus the indicator G4-LA9 of Sacombank was score at $50 \%$ because Sacombank reported an average training hour of 107,165 but not given training hours by gender. The indicator G4-SO3 has two items, thus each item of the indicator G4-SO3 at Sacombank was given a score of $50 \%(100 \% / 2$ items $)$. The first item is the total number and percentage of operations assessed for risks related to corruption, which was scored at $25 \%$ because 
Sacombank reported the percentage of operations assessed for risks related to corruption but not given the total number. The second item is the significant risks related to corruption identified through the risk assessment, which was scored at $0 \%$ because Sacombank did not disclose any information related to the significant risks identified. Therefore, the indicator $\mathrm{G} 4-\mathrm{SO} 3$ is $25 \%(25 \%+0 \%)$.

Step 4: Calculate the average score of each indicator over a five-year period. Then, compute the total average score of all indicators for each bank

Step 5: Rank SCRE performance of each bank based the total average score of all indicators over five-year period

\subsubsection{Measurement Corporate Governance}

Construct measures of the study are presented in Table 3.1 .

Table 3.1: Corporate Governance Variables Listing

\begin{tabular}{|c|c|c|c|}
\hline $\begin{array}{l}\text { Variable } \\
\text { name }\end{array}$ & $\begin{array}{l}\text { Variab } \\
\text { le code }\end{array}$ & $\begin{array}{l}\text { Variable } \\
\text { descriptio } \\
\text { n }\end{array}$ & References \\
\hline $\begin{array}{l}\text { Board of } \\
\text { Director } \\
{ }^{1} \text { Size }\end{array}$ & CG1 & $\begin{array}{l}\text { The } \\
\text { number of } \\
\text { members } \\
\text { on board } \\
\text { of director } \\
\text { including } \\
\text { a chair } \\
\text { person } \\
\text { and } \\
\text { independe } \\
\text { nt } \\
\text { directors. }\end{array}$ & $\begin{array}{l} \\
\text { adapted from } \\
\text { Miras-Rodríg } \\
\text { uez et al. } \\
(2018)\end{array}$ \\
\hline $\begin{array}{l}\text { Board } \\
\text { independen } \\
\text { ce }\end{array}$ & CG2 & $\begin{array}{l}\text { The } \\
\text { number of } \\
\text { independe } \\
\text { nt } \\
\text { directors } \\
\text { in board. }\end{array}$ & $\begin{array}{l}\text { Pillai and } \\
\text { Al-Malkawi } \\
(2018) \\
\text { Detthamrong } \\
\text { et al. }(2017)\end{array}$ \\
\hline $\begin{array}{l}\text { Female } \\
\text { chairman }\end{array}$ & CG3 & $\begin{array}{l}\text { The } \\
\text { female } \\
\text { directors } \\
\text { are } \\
\text { chairman } \\
\text { in board. }\end{array}$ & $\begin{array}{l}\text { Naciti (2019a) } \\
\text { Khan et al. } \\
(2013 b) \\
\text { Haniffa and } \\
\text { Cooke (2005) }\end{array}$ \\
\hline $\begin{array}{l}\text { Board of } \\
\text { Director } \\
\text { nationality } \\
\text { diversity }\end{array}$ & CG4 & $\begin{array}{l}\text { The ratio } \\
\text { of number } \\
\text { of foreign } \\
\text { directors } \\
\text { to the } \\
\text { total } \\
\text { number of } \\
\text { directors }\end{array}$ & \\
\hline
\end{tabular}

${ }^{1}$ In Indonesia, Board of Commission has the same function as Board of Directors in Vietnam

\begin{tabular}{|l|l|l|}
\hline & & in board. \\
\hline $\begin{array}{l}\text { Board of } \\
\text { Director } \\
\text { gender } \\
\text { diversity }\end{array}$ & $\begin{array}{l}\text { The ratio } \\
\text { of number } \\
\text { of female } \\
\text { directors } \\
\text { to the } \\
\text { total } \\
\text { number of } \\
\text { directors } \\
\text { in board. }\end{array}$ \\
\hline Firm age & CG6 & $\begin{array}{l}\text { Total } \\
\text { years } \\
\text { listed in } \\
\text { stock } \\
\text { exchange. }\end{array}$ \\
\hline $\begin{array}{l}\text { External } \\
\text { audit } \\
\text { reputation }\end{array}$ & CG7 & $\begin{array}{l}\text { Firm's } \\
\text { external } \\
\text { auditor is } \\
\text { one of big } \\
\text { four } \\
\text { auditing } \\
\text { companie } \\
\text { s. }\end{array}$ \\
\hline
\end{tabular}

(Source: Author, 2021)

\subsection{Qualitative Comparative Analysis using Fs QCA} 3.0

\subsubsection{Qualitative Comparative Analysis (QCA) method}

QCA was first proposed by Ragin (1987) as a method that enables researchers to assess cause-effect relationships between conditions and outcome variables. QCA has been used widely in the social sciences (Nair and Howlett, 2015; Fischer, 2017) This method offers "the best features of the case-oriented approach with the best features of the variable - oriented approach" (Ragin, 1987). This method enables researchers to balance between qualitative and quantitative approaches. Case-oriented approach is typically of qualitative research that produces in depth and detailed accounts of cases as a whole. The case-oriented study has been criticized because it focuses on one or a few cases, which make it hard to generalize their finding. When dealing with multiple cases, the case-oriented study often lacks a systematic and transparent method for cross case comparison. By contrast, the variable-oriented approach is typically quantitative research which enables analysis of large samples or populations and systematic cross case comparison. This does not allow researchers to obtain detailed information about individual case. QCA falls somewhere in the middle with the aim of integrating the advantages of both methodological approaches (Rihoux, 2009; Fritzsche, 2013). The aim of QCA is to clarify the group of variables, or conditions that are shared by the cases that display the same outcome so as to understand

\footnotetext{
2 The big four auditing firms include KPMG, Deloitte,
} PricewaterhouseCoopers and Ernst \&Young. 
the way in which they combine to produce it (Mahoney, 2004). The impact a condition has an outcome was determined by the other variables within the case and the way in which they coincide and interconnect, which enable the classification of descriptively meaningful patterns of interaction (Ragin, 1984). QCA is not concerned how the single independent variables have impact on a dependent variable but rather how the conditions combine to produce the outcome. As such, QCA provides a deterministic understanding in terms of the consistent patterns that occur (or do not occur) when outcomes are present, or are indeed absent (Ragin, 2018).

QCA involves six major steps: theoretical knowledge, research design, case knowledge, calibration, truth table and logical minimization. Theoretical knowledge is of general importance for the research process which refers to theories and concepts as well as related terms in the literature about a topic of interest. Base on theoretical knowledge provided, a research design is developed and then the researchers proceed with building knowledge about selected cases.

The process of assigning set membership to empirical data is called calibration. Researchers give scores to cases which reflect whether or the extent to which cases are member of sets. For the purpose of our research, crisp-set QCA is used. In set theory, the crisp-set allows only for full case membership or full non-membership to the set. This requires that all conditions and outcome for each case be dichotomized to in or out without middle position. To be more precise, scoring includes zero and one point. Zero is fully out that means a case does not have a condition so the condition is absence. By contrast, one in fully in that means a case does have a condition so the condition is present. Specially, in order to translate data into set membership scores, the researchers should develop rules on the basis on theoretical reasons and their substantive knowledge of a particular topic data set.

After calibration, the data matrix is created, which indicates the degree to which cases are members of the sets of cases with certain outcome and conditions. Each row of data matrix mentions set membership scores for one case. The data matrix is subsequently transformed into a truth table which indicates with binary scores ones and zeros which combinations of present and absent conditions lead to the outcome. The truth table is analyzed through what is called logical minimization, which amounts to a systematic comparison between cases. A summary of the most straightforward set of conditions that explains an outcome is established by way of logical minimization (Miethe, 2004).

\subsubsection{Data analysis using QCA with Fs QCA 3.0}

Fs QCA 3.0 is one of the most widely used software in scientific research to analysis data matrix for QCA. FsQCA3.0 analyses both crisp set and fuzzy set data matrix (Ragin, 2018). There are three steps to analyze the data using Fs QCA3.0, the raw data must be transformed to a data matrix via calibration and we need to upload a final data matrix and then make a truth table. Lastly, we have to minimize the truth table, is also called "logical minimization" (Kahwati and Kane, 2018)

In this study, set can be observed as groups of cases with the outcome and with the conditions of interest. The outcome, the condition and the case are three main elements which have important roles in the whole process. The research design is about what you want to examine and how you want to do the examination. In our study, we want to analyze and look into the relationship between corporate sustainability reporting (CSRE) and corporate governance indicators. To that purpose, we use crisp-set QCA to test existing theory as well as develop theory by exploring how conditions and an outcome relate to each other.

In the calibration phase, we have an overview and general evaluation of data collected from the annual reports of banks in Vietnam and Indonesia. Besides, we also assess the frequency with which data appear between two countries to decide the cut-off point in a reasonable and accurate way.

The outcome in this study is the CSRE performance being expressed in term of high CSRE performance and low CSRE performance. The reports with a score equal or higher than $900 \%$ was considered as high performance whereas those with a score lower than $900 \%$ was considered as low performance. The banks with high CSRE performance were calibrated as " 1 " whereas their counterparts were calibrated as " 0 ".

This hypothetical study has 7 conditions that are related to corporate governance disclosures. The first condition for this hypothetical study is the board of director size being expressed in term of high BOD size and low BOD size. The reports with a score greater than three are assigned as high BOD size and those that are below as low BOD size. The banks with high BOD size were marked as " 1 " whereas their counterparts were marked as " 0 ".

The second condition is the board independence being measured in term of high independent members and low independent members in board. The banks with equal or greater than one independent member are considered as high board independence and were calibrated as "1" whereas those that are below as low board independence and were calibrated as " 0 ".

Female chairman is the third condition of interest, which is examined in view of high female chairman and low female chairman. The number of women holding chairman position in banks of both Vietnam and Indonesia is very low. Therefore, the author rates 1 point for bank which has female chairman as high female chairman and 0 point for none as low female chairman.

The forth condition of interest is the BOD nationality diversity being expressed in respect of high BOD nationality diversity and low BOD nationality diversity. 
The reports with a score higher than $0 \%$ were assessed as high BOD nationality diversity, while those with a score lower than $0 \%$ were assessed as low BOD nationality diversity. The banks with high foreign members in board were calibrated as "1", while their counterparts were calibrated as " 0 ".

The BOD gender diversity is the fifth condition, which is represents for high BOD gender diversity and low BOD gender diversity. The reports with a score is greater than $0 \%$ were examined as high BOD gender diversity whereas those with a score lower than $0 \%$ were examined as low BOD gender diversity. The banks with high female members in board were rated as " 1 ", while their counterparts were rated as " 0 ".

The sixth condition of interest is firm age being concerned with high firm age and low firm age. If the banks joined in the stock exchange and disclosed the listed year in annual reports, they were considered as high firm age and calibrated as " 1 " whereas those that did not join in were considered as low firm age and calibrated as " 0 ".

The last condition is the external audit reputation being showed in term high external audit reputation and low external audit reputation. The banks which choose Big 4 auditing firms were examined as high external audit reputation and calibrated as "1". Nevertheless, those without using Big 4 auditors were considered as low external audit reputation and calibrated as " 0 ".

Table 3.2: Calibration of Corporate Sustainability Reporting and Corporate Governance variables

\begin{tabular}{|c|c|c|c|c|}
\hline & $\begin{array}{l}\text { Variable } \\
\text { name }\end{array}$ & $\begin{array}{l}\text { Cod } \\
\text { e }\end{array}$ & $\begin{array}{l}\text { Low } \\
\text { (coded } \\
\text { as 0) }\end{array}$ & $\begin{array}{l}\text { High } \\
\text { (coded } \\
\text { as 1) }\end{array}$ \\
\hline $\begin{array}{l}\text { The } \\
\text { outcom } \\
\text { e }\end{array}$ & $\begin{array}{l}\text { Corporate } \\
\text { Sustainabilit } \\
\text { y Reporting }\end{array}$ & $\begin{array}{l}\text { CSR } \\
\mathrm{E}\end{array}$ & $\begin{array}{l}\text { Smaller } \\
\text { than } \\
900 \%\end{array}$ & $\begin{array}{l}\text { Greater } \\
\text { than or } \\
\text { equal to } \\
900 \%\end{array}$ \\
\hline \multirow{5}{*}{$\begin{array}{l}\text { The } \\
\text { conditi } \\
\text { on }\end{array}$} & $\begin{array}{l}\text { Board of } \\
\text { Director } \\
\text { size }\end{array}$ & CG1 & $\begin{array}{l}\text { Smaller } \\
\text { than or } \\
\text { equal to } \\
3 \text { persons }\end{array}$ & $\begin{array}{l}\text { Greater } \\
\text { than } \\
3 \\
\text { persons }\end{array}$ \\
\hline & $\begin{array}{l}\text { Board } \\
\text { independen } \\
\text { ce }\end{array}$ & CG2 & $\begin{array}{l}\text { No } \\
\text { person }\end{array}$ & $\begin{array}{l}\text { Greater } \\
\text { than or } \\
\text { equal to } \\
1 \text { person }\end{array}$ \\
\hline & $\begin{array}{l}\text { Female } \\
\text { chairman }\end{array}$ & CG3 & $\begin{array}{l}\text { No } \\
\text { person }\end{array}$ & $\begin{array}{l}\text { Have } 1 \\
\text { person }\end{array}$ \\
\hline & $\begin{array}{l}\text { Board of } \\
\text { Director } \\
\text { nationality } \\
\text { diversity }\end{array}$ & CG4 & $0 \%$ & $\begin{array}{l}\text { Greater } \\
\text { than } 0 \%\end{array}$ \\
\hline & $\begin{array}{l}\text { Board of } \\
\text { Director }\end{array}$ & CG5 & $0 \%$ & $\begin{array}{l}\text { Greater } \\
\text { than } 0 \%\end{array}$ \\
\hline
\end{tabular}

\begin{tabular}{|l|l|l|l|l|}
\hline & $\begin{array}{l}\text { gender } \\
\text { diversity }\end{array}$ & CG6 & $\begin{array}{l}\text { No listed } \\
\text { on the } \\
\text { stock } \\
\text { exchange }\end{array}$ & $\begin{array}{l}\text { Listed } \\
\text { on the } \\
\text { stock } \\
\text { exchang } \\
\text { e }\end{array}$ \\
\hline & $\begin{array}{l}\text { External } \\
\text { audit } \\
\text { reputation }\end{array}$ & CG7 & $\begin{array}{l}\text { No big4 } \\
\text { company } \\
\text { audit }\end{array}$ & $\begin{array}{l}\text { Big 4 } \\
\text { compan } \\
\text { y audit }\end{array}$ \\
\hline
\end{tabular}

(Source: Author, 2021)

\section{DATA ANAYSIS AND FINDINGS}

\subsection{CSR Evaluation of CSRE performance}

We scored 48 indicators of social pillar for each bank by employing scoring method (see detail in section 3.2.1). After that, the average score of each indicator is calculated over a five-year period. Then, the total average score of all indicators is computed for each bank. The table 4.1 illustrates score of some performance indicator based on GRI-G4 standard of ACB in 5 years from 2014 to 2018.

Table 4.1: ACB's CSRE performance based on G4 GRI

Unit: percentage $(\%)$

\begin{tabular}{|l|l|l|l|l|l|l|}
\hline $\begin{array}{l}\text { Indicator } \\
\text { s }\end{array}$ & $\begin{array}{l}\mathbf{2 0 1} \\
\mathbf{4}\end{array}$ & $\begin{array}{l}\mathbf{2 0 1} \\
\mathbf{5}\end{array}$ & $\begin{array}{l}\mathbf{2 0 1} \\
\mathbf{6}\end{array}$ & $\begin{array}{l}\mathbf{2 0 1} \\
\mathbf{7}\end{array}$ & $\mathbf{2 0 1 8}$ & $\begin{array}{l}\text { Avera } \\
\text { ge }\end{array}$ \\
\hline G4-SO1 & $\begin{array}{l}25,0 \\
0\end{array}$ & $\begin{array}{l}25,0 \\
0\end{array}$ & $\begin{array}{l}31,5 \\
0\end{array}$ & $\begin{array}{l}25,0 \\
0\end{array}$ & $\begin{array}{l}31,5 \\
0\end{array}$ & $\mathbf{2 7 , 6 0}$ \\
\hline G4-SO3 & 0,00 & 0,00 & 0,00 & 0,00 & $\begin{array}{l}25,0 \\
0\end{array}$ & $\mathbf{5 , 0 0}$ \\
\hline G4-LA2 & $\begin{array}{l}50,0 \\
0\end{array}$ & $\begin{array}{l}50,0 \\
0\end{array}$ & $\begin{array}{l}50,0 \\
0\end{array}$ & $\begin{array}{l}50,0 \\
0\end{array}$ & $\begin{array}{l}50,0 \\
0\end{array}$ & $\mathbf{5 0 , 0 0}$ \\
\hline G4-LA9 & $\begin{array}{l}50,0 \\
0\end{array}$ & 0,00 & $\begin{array}{l}50,0 \\
0\end{array}$ & $\begin{array}{l}50,0 \\
0\end{array}$ & $\begin{array}{l}50,0 \\
0\end{array}$ & $\mathbf{4 0 , 0 0}$ \\
\hline Total & $\begin{array}{l}\mathbf{4 6 7 ,} \\
\mathbf{5 0}\end{array}$ & $\begin{array}{l}\mathbf{3 8 2}, \\
\mathbf{5 0}\end{array}$ & $\begin{array}{l}\mathbf{4 2 4}, \\
\mathbf{0 0}\end{array}$ & $\begin{array}{l}\mathbf{4 6 0}, \\
\mathbf{0 0}\end{array}$ & $\begin{array}{l}\mathbf{4 6 4}, \mathbf{0 0} \\
\mathbf{4 3 9 , 6}\end{array}$ \\
\hline
\end{tabular}

(Source: Author, 2021)

SCRE performance for all banks is ranked base on the total average score of all indicators over five-year period. Table 4.2 and Table 4.3 shows ranking of CSRE performance of listed banks in Vietnam and Indonesia respectively (2014-2018). 
Table 4.2: Ranking of CSRE performance of listed banks in Vietnam (2014-2018)

Unit: percentage $(\%)$

\begin{tabular}{|l|l|l|}
\hline Rank & Bank & Total Average \\
\hline 1 & & \\
\hline 2 & STB & 2019,91 \\
\hline 3 & HDB & 898,44 \\
\hline 4 & BID & 681,50 \\
\hline 5 & CTG & 478,55 \\
\hline 6 & ACB & 439,60 \\
\hline 7 & SHB & 408,75 \\
\hline 8 & TCB & 378,75 \\
\hline 9 & VPB & 365,00 \\
\hline 10 & VCB & 363,00 \\
\hline 11 & EIB & 355,00 \\
\hline 12 & MBB & 346,25 \\
\hline 13 & TPB & 297,25 \\
\hline
\end{tabular}

(Source: Author, 2021)

Table 4.3: Ranking of CSRE performance of listed banks in Indonesia (2014-2018)

Unit: Percentage (\%)

\begin{tabular}{|l|l|l|}
\hline Rank & Bank & Total Average \\
\hline 1 & DKI & 1985,94 \\
\hline 2 & RiauKepri & 1722,81 \\
\hline 3 & Kalbar & 1578,13 \\
\hline 4 & Jateng & 1576,00 \\
\hline 5 & Kalsel & 1533,75 \\
\hline 6 & BPD DIY & 1490,00 \\
\hline 7 & Sulselbar & 1466,25 \\
\hline 8 & Sumut & 1458,75 \\
\hline 9 & Kaltimtara & 1447,25 \\
\hline 10 & Jatim & 1402,50 \\
\hline 11 & Nagari & 1362,50 \\
\hline
\end{tabular}

\begin{tabular}{|l|l|l|}
\hline 12 & Jambi & 1201,25 \\
\hline
\end{tabular}

(Source: Author, 2021)

The improvement or deterioration of SCRE performance is over a five-year period by comparing the score of each performance indicator between 2018 and 2014. If the difference is positive, it is classified as improvement. If the difference is negative, it is classified as deterioration. If there is no difference, it is classified as unchanged. Table shows the number of indicators are improved and deteriorated from 2014 to 2018 . Table 4.4 and Table 4.5 shows changes in CSRE performance of listed banks in Vietnam and Indonesia respectively (2014-2018).

Table 4.4: Changing in CSRE performance of listed bank in Vietnam (2014-2018)

\begin{tabular}{|l|l|l|}
\hline Bank & Improvement & Deterioration \\
\hline ACB & 3 & 1 \\
\hline NVB & 0 & 7 \\
\hline SHB & 3 & 0 \\
\hline EIB & 3 & 0 \\
\hline CTG & 7 & 0 \\
\hline BID & 8 & 0 \\
\hline HDB & 21 & 2 \\
\hline MBB & 2 & 0 \\
\hline STB & 4 & 26 \\
\hline TCB & 4 & 3 \\
\hline TPB & 2 & 1 \\
\hline VCB & 1 & 1 \\
\hline VPB & 4 & 0 \\
\hline
\end{tabular}

(Source: Author, 2021)

Table 4.5: Changing in CSRE performance of listed bank in Vietnam (2014-2018)

\begin{tabular}{|l|l|l|}
\hline Bank & Improvement & Deterioration \\
\hline BPD DIY & 13 & 0 \\
\hline DKI & 4 & 3 \\
\hline Kalbar & 2 & 4 \\
\hline Kalsel & 0 & 0 \\
\hline Kaltimtara & 2 & 0 \\
\hline
\end{tabular}




\begin{tabular}{|l|l|l|}
\hline RiauKepri & 1 & 0 \\
\hline Jateng & 5 & 0 \\
\hline Jambi & 0 & 1 \\
\hline Sulselbar & 10 & 1 \\
\hline Jatim & 4 & 0 \\
\hline Sumut & 6 & 0 \\
\hline Nagari & 1 & 0 \\
\hline
\end{tabular}

(Source: Author, 2021)

\subsection{Relationship between CSRE and Corporate} Governance in Vietnam and Indonesia

Table 4.6 and Table 4.7 presents examples of data collected for ACB (a listed Vietnamese bank) and BPD DIY (an Indonesian Islamic bank) between 2014 and 2018 respectively before calibration.

Table 4.6: Data collected for ACB (2014-2018)

\begin{tabular}{|c|c|c|c|c|c|}
\hline \multirow{2}{*}{$\begin{array}{l}\text { Variabl } \\
\text { e } \\
\text { Code } \\
\end{array}$} & \multicolumn{5}{|c|}{ Bank ACB } \\
\hline & 2014 & 2015 & 2016 & 2017 & 2018 \\
\hline CSRE & 467,50 & 382,50 & 424,00 & 460,00 & 464,00 \\
\hline CG1 & 10 & 10 & 9 & 9 & 8 \\
\hline CG2 & 1 & 1 & 1 & 1 & 2 \\
\hline CG3 & 0 & 0 & 0 & 0 & 0 \\
\hline CG4 & $\begin{array}{l}30.00 \\
\%\end{array}$ & $\begin{array}{l}30.00 \\
\%\end{array}$ & $\begin{array}{l}22.22 \\
\%\end{array}$ & $\begin{array}{l}22.22 \\
\%\end{array}$ & $\begin{array}{l}25.00 \\
\%\end{array}$ \\
\hline CG5 & $\begin{array}{l}20.00 \\
\%\end{array}$ & $\begin{array}{l}20.00 \\
\%\end{array}$ & $\begin{array}{l}22.22 \\
\%\end{array}$ & $\begin{array}{l}22.22 \\
\%\end{array}$ & $\begin{array}{l}25.00 \\
\%\end{array}$ \\
\hline CG6 & $\begin{array}{l}\text { listed } \\
2006\end{array}$ & $\begin{array}{l}\text { listed } \\
2006\end{array}$ & $\begin{array}{l}\text { listed } \\
2006\end{array}$ & $\begin{array}{l}\text { listed } \\
2006\end{array}$ & $\begin{array}{l}\text { listed } \\
2006\end{array}$ \\
\hline CG7 & PMG & KPMG & KPMG & PWC & PWC \\
\hline
\end{tabular}

(Source: Author, 2021)

Table 4.7: Data collected for BPD DIY (2014 - 2018)

\begin{tabular}{|c|c|c|c|c|c|}
\hline \multirow{2}{*}{$\begin{array}{l}\text { Var } \\
\text { Cod } \\
\text { e }\end{array}$} & \multicolumn{5}{|c|}{ Bank ACB } \\
\hline & 2014 & 2015 & 2016 & 2017 & 2018 \\
\hline $\begin{array}{l}\text { CSR } \\
\text { E } \\
\end{array}$ & 1187,5 & 1414,5 & 1412,5 & 1412,5 & 2025,5 \\
\hline CG1 & 3 & 3 & 3 & 3 & 3 \\
\hline CG2 & 1 & 1 & 1 & 1 & 1 \\
\hline CG3 & 0 & 0 & 0 & 0 & 0 \\
\hline
\end{tabular}

\begin{tabular}{|l|l|l|l|l|l|}
\hline CG4 & 0 & 0 & 0 & 0 & 0 \\
\hline CG5 & 0 & 0 & 0 & 0 & 0 \\
\hline CG6 & 0 & 0 & 0 & 0 & 0 \\
\hline CG7 & $\begin{array}{l}\text { KRES } \\
\text { TON }\end{array}$ & $\begin{array}{l}\text { KRES } \\
\text { TON }\end{array}$ & $\begin{array}{l}\text { KRES } \\
\text { TON }\end{array}$ & $\begin{array}{l}\text { KRES } \\
\text { TON }\end{array}$ & $\begin{array}{l}\text { KRES } \\
\text { TON }\end{array}$ \\
\hline
\end{tabular}

(Source: Author, 2021)

The calibration was conducted to transfer the raw data to data matrix table as shown in Table 4.8 and Table 4.9 for ACB bank and BPD DIY bank between 2014 and 2018 respectively.

Table 4.8: Data matrix of ACB bank (2014-2018)

\begin{tabular}{|c|c|c|c|c|c|c|}
\hline & \multirow[b]{2}{*}{$\begin{array}{l}\text { Variabl } \\
\text { e code }\end{array}$} & \multicolumn{5}{|c|}{ ACB } \\
\hline & & $\begin{array}{l}201 \\
4\end{array}$ & $\begin{array}{l}201 \\
5\end{array}$ & $\begin{array}{l}201 \\
6\end{array}$ & $\begin{array}{l}201 \\
7 \\
\end{array}$ & $\begin{array}{l}201 \\
8\end{array}$ \\
\hline $\begin{array}{l}\text { The } \\
\text { outcom } \\
\text { e }\end{array}$ & CSRE & 0 & 0 & 0 & 0 & 0 \\
\hline \multirow{7}{*}{$\begin{array}{l}\text { The } \\
\text { conditio } \\
\mathrm{n}\end{array}$} & CG1 & 1 & 1 & 1 & 1 & 1 \\
\hline & CG2 & 1 & 1 & 1 & 1 & 1 \\
\hline & CG3 & 0 & 0 & 0 & 0 & 0 \\
\hline & CG4 & 1 & 1 & 1 & 1 & 1 \\
\hline & CG5 & 1 & 1 & 1 & 1 & 1 \\
\hline & CG6 & 1 & 1 & 1 & 1 & 1 \\
\hline & CG7 & 1 & 1 & 1 & 1 & 1 \\
\hline
\end{tabular}

(Source: Author, 2021)

Table 4.9: Data matrix of BPD DIY bank (2014-2018)

\begin{tabular}{|c|c|c|c|c|c|c|}
\hline & \multirow{2}{*}{$\begin{array}{l}\text { Variabl } \\
\text { e code }\end{array}$} & \multicolumn{5}{|c|}{ BPD DIY } \\
\hline & & $\begin{array}{l}201 \\
4\end{array}$ & $\begin{array}{l}201 \\
5 \\
\end{array}$ & $\begin{array}{l}201 \\
6\end{array}$ & $\begin{array}{l}201 \\
7\end{array}$ & $\begin{array}{l}201 \\
8\end{array}$ \\
\hline $\begin{array}{l}\text { The } \\
\text { outcom } \\
\text { e }\end{array}$ & CSRE & 1 & 1 & 1 & 1 & 1 \\
\hline \multirow{7}{*}{$\begin{array}{l}\text { The } \\
\text { conditio } \\
\mathrm{n}\end{array}$} & CG1 & 0 & 1 & 1 & 1 & 1 \\
\hline & CG2 & 1 & 1 & 1 & 1 & 1 \\
\hline & CG3 & 0 & 0 & 0 & 0 & 0 \\
\hline & CG4 & 0 & 1 & 1 & 1 & 1 \\
\hline & CG5 & 0 & 1 & 1 & 1 & 1 \\
\hline & CG6 & 0 & 1 & 1 & 1 & 1 \\
\hline & CG7 & 0 & 1 & 1 & 1 & 1 \\
\hline
\end{tabular}

(Source: Author, 2021)

After calibration base on scrip options in QCA, the 
results of data analysis indicating corporate governance configuration for high CSRE performance is presented in Table 4.10

Table 4.10: Corporate governance configuration for high CSRE performance

\begin{tabular}{|c|c|c|c|c|}
\hline & \multicolumn{4}{|c|}{$\begin{array}{l}\text { Solutions }{ }^{\mathrm{a}} \text { ( sufficient causal conditions for } \\
\text { High CSRE) }\end{array}$} \\
\hline & Code & A & B & C \\
\hline $\begin{array}{l}\text { Board of } \\
\text { Director } \\
\text { Size }\end{array}$ & CG1 & & $\bullet$ & $\bullet$ \\
\hline $\begin{array}{l}\text { Board } \\
\text { Independe } \\
\text { nce }\end{array}$ & CG2 & $\bullet$ & $\bullet$ & $\bullet$ \\
\hline $\begin{array}{l}\text { Female } \\
\text { Chairman }\end{array}$ & CG3 & & & $\bullet$ \\
\hline $\begin{array}{l}\text { BOD } \\
\text { Diversity } \\
\text { Nationalit } \\
\mathrm{y}\end{array}$ & CG4 & $\otimes$ & $\otimes$ & $\bullet$ \\
\hline $\begin{array}{l}\text { BOD } \\
\text { Diversity } \\
\text { Gender }\end{array}$ & CG5 & & $\otimes$ & $\bullet$ \\
\hline Firm Age & CG6 & $\otimes$ & $\otimes$ & $\bullet$ \\
\hline $\begin{array}{l}\text { External } \\
\text { Audit } \\
\text { Reputatio } \\
\mathrm{n}\end{array}$ & CG7 & $\otimes$ & $\otimes$ & • \\
\hline $\begin{array}{l}\text { Consisten } \\
\text { cy }\end{array}$ & & 1 & 1 & 1 \\
\hline $\begin{array}{l}\text { Coverage } \\
\text { (raw) }\end{array}$ & & $\begin{array}{l}0.7704 \\
92\end{array}$ & 0.295082 & $\begin{array}{l}0.0163 \\
934\end{array}$ \\
\hline $\begin{array}{l}\text { Coverage } \\
\text { (unique) }\end{array}$ & & $\begin{array}{l}0.5081 \\
97\end{array}$ & $\begin{array}{l}0.032786 \\
8\end{array}$ & $\begin{array}{l}0.0163 \\
934\end{array}$ \\
\hline $\begin{array}{l}\text { Overall } \\
\text { Consisten } \\
\text { cy }\end{array}$ & 1 & & & \\
\hline $\begin{array}{l}\text { Overall } \\
\text { coverage }\end{array}$ & 0.819672 & & & \\
\hline $\begin{array}{l}\text { Examples } \\
\text { (sample) }\end{array}$ & & $\begin{array}{l}\text { BPDD } \\
\text { IY201 } \\
4 \\
\text { INDO }\end{array}$ & $\begin{array}{l}\text { DKI2018 } \\
\text { INDO }\end{array}$ & $\begin{array}{l}\text { HDB20 } \\
18 \\
\text { VIE } \\
\end{array}$ \\
\hline & & $\begin{array}{l}\text { DKI20 } \\
18 \\
\text { INDO }\end{array}$ & $\begin{array}{l}\text { KALBA } \\
\text { R2014 } \\
\text { INDO }\end{array}$ & \\
\hline & & $\begin{array}{l}\text { KALB } \\
\text { AR201 } \\
4\end{array}$ & $\begin{array}{l}\text { JATIM20 } \\
1 \\
\text { 5INDO }\end{array}$ & \\
\hline
\end{tabular}

\begin{tabular}{|l|l|l|l|l|}
\hline & & INDO & & \\
\hline & & KALS & & \\
& & EL201 & KALSEL & \\
& 5 & 2015 & \\
& & INDO & INDO & \\
\hline & & RIAU2 & KALTIM & \\
& & 015 & 2017 & \\
& & INDO & INDO & \\
\hline & & KALTI & NAGA2 & \\
& & M2016 & 016 & \\
& & INDO & INDO & \\
\hline
\end{tabular}

(Source: Author, 2021)

- Presence of conditions; $\otimes$ Absence of conditions; Blank cells: non-binding conditions (i.e., the condition can be either present or absent in that configuration).

A striking feature of QCA that is different from regression analysis is identify which set of causal conditions leading to presence of the outcome (Fiss, 2011). Given this QCA feature, we performed a test of causal conditions (corporate governance variables) leading to high CSRE performance of banks in Vietnamese and Indonesia. Table 4.19 presents results from data analysis using Fs QCA 3.0 as suggested by Fiss (2011) to ensure simplify readability of research findings. Black circles $(\bullet)$ indicate the presence of a condition, circles with a cross-out $(\otimes)$ indicate the absence of a condition, and the blank spaces indicate a situation where a condition can be either present or absence for the configuration.

The study finds three configurations that are sufficiently linked to high CSRE performance of banks in Vietnam and Indonesia. In other words, three causal paths are found to explain high CSRE performance and each displays a consistency as 1 that is higher than 0.75 threshold. Overall consistency is 1 overall coverage is approximately 0.82 , which indicates validity of the findings (Ragin, 2008; Schneider, 2010). The first configuration (column A) is found in Indonesian banking with an Islamic legal system. This configuration indicates that banks with the board independence (board independence members are bigger or equal 1 member), no diversity on nationality of BOD, no listed on the Stock Exchange and no hiring Big 4 Auditing companies have high CSRE performance. The presence or absence of other corporate governance variables (BODs size, Female chairman and BOD gender diversity) do not affect CSRE performance.

The second configuration (column B) is also found in Indonesia, which indicates that banks with large BOD size and board of independence, no diversity on nationality of BOD, BOD gender diversity, no listed on the Stock Exchange and no hiring Big 4 Auditing companies have high CSRE performance leading. The 
presence or absence of Female chairman do not affect CSRE performance. The third configuration (column C) is found in Vietnamese context. It shows that Vietnamese achieved high CSRE performance need presence of seven corporate governance variables, namely: large BOD size, board independence, board of director national diversity, board of director gender diversity, firm age and external audit reputation.

In summary, there is a big difference regarding the causal path of corporate governance variables explaining high CSRE performance of banks in Vietnam and Indonesia. Specifically, high CSRE performance of Islamic banks in Indonesia is governed by two main factors: board size and board independence. Meanwhile, listed banks in Vietnam achieve high CSRE performance when seven corporate governance variables, namely: large BOD size, board independence, board of director national diversity, board of director gender diversity, firm age and external audit reputation, are present.

\section{CONCLUSIONS}

\subsection{Conclusions and limitations}

The first findings of the study show ranking on CSRE performance of banks in Vietnam and Indonesia from 2014 to 2018. In addition, the results report improvement and deterioration of the banks between 2014 and 2018 . Furthermore, the study finds three configurations or three causal paths that lead to high CSRE performance in Vietnam and Indonesia. In Indonesia, In Indonesia, two configurations highlights presence of board independence and large Board of Director (BOD) size as two important corporate governance variables resulting in high CSRE performance of Islamic banks. In Vietnam, listed banks achieve high CSRE performance only when seven corporate governance variables, namely large BOD size, board independence, female chairman, BOD nationality diversity, BOD gender diversity, firm age and external audit reputation, are presented.

\subsection{Discussions of the findings}

CSRE performance of listed banks in Vietnam was worse than that of Islamic banks in Indonesia. CSRE based on GRI-G4 framework was employed in few listed banks in Vietnam. In developing country, Habib Zaman et al. (2009), CSRE practices are infant, which might cause low CSRE performance. Tschopp (2005) noted that CSR reporting can be "camouflaged" and would be not interpreted the company's actual position. However, Islamic banking complies with sharia (Islamic law) and practice activities through Islamic economic model, which, a mechanism of safekeeping, profit sharing, and loss-bearing, which might be a reason for high CSRE in social index of Indonesian firms. In general, most of the firm's reporting improved among five years in social disclosure. BODs pay attention to report performance especially social issue, which was significant impact on ability to increase the amount of relevant information provided to shareholders and stock exchange markets (Lemus, 2016).

This study found three configurations resulted in high CSRE performance. The first configuration is presence of board independence and absence of BOD nationality diversity, firm age, external audit reputation. The second configuration is presence of board size, board independence and absence of BOD nationality diversity, BOD gender diversity firm age, external audit reputation. The third configuration is presence of seven factors in corporate governance variables.

The study found that board independence is an important affect CSRE performance of Islamic banks in Indonesia. The finding is consistent with prior studies that found positive effects of board independence on CSRE performance (e.g. Lattemann, 2009; Khan et al., 2013a). Similarly, Michelon (2012) claimed the more independent directors the better CSR. The studies showed opposite arguments that board independence effects negative CSRE performance (Haniffa, 2005; Said, 2009; Michelon, 2012). Furthermore, the combination of two factors board independence and large BOD size leads to high CSRE performance. The finding is consistent with prior studies that find positive relationships between large BOD size and CSRE performance (Lipton and Lorsch, 1992; Kiel. C.G. and Nicholson.J.G., 2003; Leblanc and Gillies, 2003). Finally, the configuration that leads to high performance requires presence of seven corporate variables the context of listed banks in Vietnam.

\subsection{Implications of the study}

This study contributes to extant CSR literature, especially CSR evidence in developing countries like Vietnam and Indonesia (Sahay.A, 2004; Yusoff.S et al., 2007; Khan et al., 2009). The findings provide bank managers an overview on their bank performance on CSRE, which enables them to address importance and relevance of their organizations' wellbeing. As such, managers might focus more on CSRE to realize firm weaknesses to enhance future firm performance. Moverver, ranking CSRE performance provides stakeholders with an index for comparing CSRE performance among listed banks in Vietnam and Islamic banks in Indonesia, which allows them to participate in monitoring social performance of banks. CSR need to engage stakeholders in carrying out the materiality analysis by which organizations can identify their most relevant sustainability aspects (Nicola .B et al., 2016). Additionally, the findings enables banks managers in Vietnam and Indonesia to focus certain configurations or causal paths of corporate governance leading to high CSRE performance, which contributes to agency problems and maximize alignment of interests between firms and their stakeholders.

\subsection{Limitations}

The findings are subject to subjectivity under scoring method and QCAcalibration, which is typical limitation of these methods. 


\section{REFERENCES}

[1]. Abbott, W.F. and Monsen, R.J. (1979) 'On the Measurement of Corporate Social Responsibility: Self-Reported Disclosures as a Method of Measuring Corporate Social Involvement', Academy of Management Journal, 22(3), 501-515.

[2]. Abdul Rashid, M.Z. and Ibrahim, S. (2002) 'Executive and Management Attitudes towards Corporate Social Responsibility in Malaysia', Corporate Governance, Vol.2(No.4), pp. 10-16.

[3]. Adams, R.B., Ferreira, D. (2009) 'Women in the boardroom and their impact on governance and performance', Journal of Financial Economics, 94(2), pp. 291-309.

[4]. Aisyah, F.C. (2017) 'The study of sustainability report disclosure aspects and their impact on the companies' performance', p. SHS Web of Conferences.

[5]. Amran, A., Lee, S.P. and \& Devi, S.S. (2014) 'The influence of governance structure and strategic corporate social responsibility toward sustainability reporting quality', Business Strategy and the Environmental Policies, 23(4), pp. 217-235.

[6]. Barako, D.G., and Alistair M. Brown (2008) 'Corporate social reporting and board representation: Evidence from the Kenyan banking sector', Journal of Management \& Governance 12, p. 309.

[7]. Bartels, W., Fogelberg, T., Hoballah, A. and Lugt, C.T.v.d. (2016) Global trends in sustainability reporting regulation and policy.

[8]. Bonsón, E., Bednárová, M. (2015) 'CSR reporting practices of Eurozone companies.', Revista De Contabilidad - Spanish Accounting Review, 18(2), pp. 182-193.

[9]. Brown, H.S., De Jong, M., Lessidrenska, T. (2009) 'The rise of the Global Reporting Institutive: a case of institutional entrepreneurship', Environmental Policies, 18(2), pp. 182-200.

[10]. Buniamin, S., Alrazi, B., Johari, N.H. and Rahman, N.R.A. (2011) 'Corporate governance practices and environmental reporting of companies in Malaysia: Finding possibilities of double thumbs up', Jurnal Pengurusan, 32(2011), pp. 55-71.

[11]. Carroll, A.B. (1999) 'Corporate Social Responsibility: Evolution of a Definitional Construct', Business \& Society, 38, pp. 268-295.

[12]. Chen, H. and \& Wang, X. (2011) 'Corporate social responsibility and corporate financial performance in China: An empirical research from Chinese firms', The International Journal of Business in Society, 11(4), pp. 361-370.

[13]. Clarkson, P., Li, Y., Gordon, R. and Vasvari, F. (2008) 'Revisiting the Relation Between Environmental Performance and Environmental Disclosure: An Empirical Analysis', Accounting, Organizations and Society, 33, pp. 303-327.

[14]. Collier and Wanderley (2005) 'Corporate Citizenship in Afica: Lessons from the Past; Paths to the future'.

[15]. Correa-Garcia, J.A., Garcia-Benau, M.A. and Garcia-Meca, E. (2020) 'Corporate governance and its implications for sustainability reporting quality in Latin American business groups', Journal of Cleaner Production, 260, p. 121142.

[16]. Daizy, Sen, M. and Das, N. (2013) 'Corporate Sustainability Reporting: A Review of Initiatives and Trends', Accountig Research and Audit Practice, vol. XII(2), pp. 7-18.

[17]. Detthamrong, U., Chancharat, N. and Vithessonthi, C. (2017) 'Corporate governance, capital structure and firm performance: Evidence from Thailand', Research in International Business and Finance, 42, pp. 689-709.

[18]. Dienes, D., \& Velte, P. (2016) 'The impact of supervisory board composition on CSR reporting. Evidence from the German two-tier system', Journal Sustainability, 8(63), pp. 1-20.

[19]. Dissanayake, Dinithi, T, C. and X-L, M. (2016a) ' Sustainability reporting by publicly listed companies in Sri Lanka', Cleaner Production.

[20]. Dissanayake, D., Tilt, C. and Xydias-Lobo, M. (2016b) 'Sustainability Reporting by Publicly Listed Companies in Sri Lanka', Journal of Cleaner Production, 129.

[21]. Dusuki AW, A.N. (2007) 'Maqasid al-Shari'ah, Maslahah, and corporate social responsibility', Am J Islam Soc Sci 45(24:25).

[22]. Dusuki AW, A.N. (2008) 'what does islam say about corporate social responsibility?', Rev Islam Econ 28(12:5).

[23]. Erhardt, N.L., Werbel, J.D., Shrader, C.B. (2003) 'Board of director diversity andfirmfinancial performance', Corp. Gov.: Int. Rev., 11, pp. 102-111.

[24]. Fernandez-Feijoo, B., et al. (2012a) 'Does Board Gender Composition affect Corporate Social Responsibility Reporting? ', International Journal of Business and Social Science 3.

[25]. Fernandez-Feijoo, B., Romero, S., \& Ruiz, S. (2012b) 'Does board gender composition affect corporate social responsibility reporting?', International Journal of Business and Social Science, 3(1), pp. 31-38. 
[26]. Fischer, M., Maggetti, M. (2017) 'Qualitative comparative analysis and the study of policy processes', J. Comp. Policy Anal. Res. Pract., 19, pp. 345-361.

[27]. Fiss, P.C. (2011) 'Building better causal theories: A fuzzy set approach to typologies in organization research', Academy of Management Journal, 54, pp. 393-420.

[28]. Fodio, M.I. and \& Oba, V.C. (2012) 'Boards' gender mix and extent of environmental responsibility information disclosure in Nigeria: An empirical study', European Journal of Business and Management, 4(14), pp. 163-169.

[29]. Frederick W, P.J., Davis KE (1992) Corporate Strategy, Public Policy, Ethics. Business and Society.

[30]. Freeman, R.E. (1984) Strategic management : a stakeholder approach. Boston: Pitman.

[31]. Fritzsche, E. (2013) 'Making hermeneutics explicit: How QCA supports an insightful dialogue between theory and cases', International Journal of Social Research Methodology 17(4), pp. 403-426.

[32]. Frost, G., S., J., J., L. and S., V.D.L. (2005) 'A Survey of Sustainability Reporting Practices of Australian Reporting Entities', Australian Accounting Review, 15(35), pp. 89-96.

[33]. Giannarakis, G. (2014) 'Corporate governance and financial characteristic effects on the extent of corporate social responsibility disclosure', Social Responsibility Journal, 10(4), pp. 569-590.

[34]. Guido Corbetta, C.A.S. (2004) 'The Board of Directors in Family Firms: One Size Fits All?', Family Business Review, 17(2), pp. 119-134.

[35]. Habib Zaman, K., Abdel Karim, H. and Martin Samy (2009) 'Corporate Social Responsibility (CSR) Reporting: A Study of Selected Banking Companies in Bangladesh', Social Responsible.

[36]. Hafsi， T., \& Turgut, G. (2013) 'Boardroom diversity and its effect on social performance: conceptualization and empirical evidence', Journal of Business Ethics, 112(3), pp. 463-479.

[37]. Halme, M. and Huse, M. (1997) 'The influence of corporate governance, industry and country factors on environmental reporting', Scandinavian Journal of Management, 13(2), pp. 137-157.

[38]. Haniffa, R. and Cooke, T. (2002) 'Culture, Corporate Governance and Disclosure in Malaysian Corporations', Abacus, 38, pp. 317-349.

[39]. Haniffa, R.M., and Terry E. Cooke (2005) 'The impact of culture and governance on corporate social reporting', Journal of Accounting and Public Policy 24, pp. 391-430.
[40]. Haniffa, R.M. and Cooke, T.E. (2005) 'The impact of culture and governance on corporate social reporting', Journal of Accounting and Public Policy, 24(5), pp. 391-430.

[41]. Haslinda Yusoff and Zunaidah Ahman (2019) 'The Influence of Corporate Governance on Corporate Social Responsibility Disclosure: A Focus on Accountability ', 23(1).

[42]. Haslinda Yusoff, Z.A., Uzma Bhd., Faizah Darus (2019) 'The Influence of Corporate Governance on Corporate Social Responsibility Disclosure: A Focus on Accountability', Academy of Accounting and Financial Studies Journal, 23(1).

[43]. Hill, C.W.L. and \& Jones, T.M. (1992) 'Stakeholder-agency theory

[44]. ', Journal of Management Studies

[45]. 29(2), pp. 131-154.

[46]. Hoang Thi Mai Khanh and Tuan, N.A. (2018) 'Determinants of sustainability reporting: An empirical research on Vietnamese Listed companies', SCIENCE \& TECHNOLOGY DEVELOPMENT JOURNAL: ECONOMICS LAW AND MANAGEMENT, 2(2).

[47]. Hussain M, S.A., Turk R (2015) 'An overview of Islamic finance', IMF Work Pap.

[48]. Hutchinson, M., Mack, J., Plastow, K. (2015) 'Who selects the'right'directors? An examination of the association between board selection, gender diversity andoutcomes', Account. Finance, 55, pp. 1071-1103.

[49]. Ibrahim, N.A., and John P. Angelidis (1995) 'The corporate social responsiveness orientation of board members: Are there differences between inside and outside directors?', Journal of business Ethics, 14, pp. 405-10.

[50]. IdilKaya (2016) 'The Mandatory Social and Environmental Reporting: Evidence from France', Procedia-Social and Behavioral Sciences, 229(19 August 2016), pp. 206-213.

[51]. Ienciu, I.-A., Popa, I.E. and Ienciu, N.M. (2012) 'Environmental Reporting and Good Practice of Corporate Governance: Petroleum Industry Case Study', Procedia Economics and Finance, 3, pp. 961-967.

[52]. Islam, M. and Chowdhury, M.A. (2017) 'Corporate sustainability reporting in the banking sector of Bangladesh: an appraisal of the G4 of the Global Reporting Initiative', International Journal of Green Economics, 10, p. 252.

[53]. Jamali and Mishak (2007) 'Coporate social responsibility (CSR) Theory and pratice in a developing country context', Business ethics, 72 362 . 
[54]. Janggu, T., et al. (2014) 'Does Good Corporate Governance Lead to Better Sustainability Reporting? An Analysis Using Structural Equation Modeling', Procedia - Social and Behavioral Sciences 145 .

[55]. Jensen, M.C., \& Meckling, W. H. Economics Social Institutions (1979) Theory of the Firm: Managerial Behavior, Agency Costs, and Ownership Structure.

[56]. Jensen, M.C. and Meckling, W.H. (1976) 'Theory of the firm: Managerial behavior, agency costs and ownership structure', Journal of Financial Economics, 3(4), pp. 305-360.

[57]. Kahwati, L.C. and Kane, H.L. (2018) Qualitative Comparative Analysis in Mixed Methods Research and Evaluation. SAGE Publications.

[58]. Kamla R, R.G. (2013) 'Social reporting by Islamic banks: does social justice matter?', Account Audit Account J, 26, pp. 911-945.

[59]. Kathe Newman and Santoro, M. (2014) 'How and Why Multinational Corporations Pursue CSR Strategies: the Case of Nestle in China. '.

[60]. Khan, A., Muttakin, M.B. and Siddiqui, J. (2013a) 'Corporate governance and corporate social responsibility disclosures: Evidence from an emerging economy', Journal of Business Ethics 114 , pp. 207-23.

[61]. Khan, A., Muttakin, M.B. and Siddiqui, J. (2013b) 'Corporate Governance and Corporate Social Responsibility Disclosures: Evidence from an Emerging Economy', Journal of Business Ethics, 114(2), pp. 207-223.

[62]. Khan, H.-U.-Z. (2010a) 'The effect of corporate governance elements on corporate social responsibility (CSR) reporting: Empirical evidence from private commercial banks of Bangladesh', International Journal of Law and Management 52, pp. 82-109.

[63]. Khan, H. (2010b) 'The effect of corporate governance elements on corporate social responsibility (CSR ) reporting: Empirical evidence from private commercial banks of Bangladesh', International Journal of Law and Managment, 52(2), pp. 82-109.

[64]. Khan, H.Z., Halabi, A.K. and Samy, M. (2009) 'Corporate Social Responsibility (CSR) Reporting: A Study of Selected Banking Companies in Bangladesh', Social Responsible.

[65]. Khanh, H.T.M., \& Tuan, N. A. (2018) 'Determinants of sustainability reporting: An empirical research on Vietnamese Listed companies. ', Science \& Technology Development Journal - Economics - Law and Management, 2(2), pp. 62-73.
[66]. Kiel. C.G. and Nicholson.J.G. (2003) 'Corporate governance and direction. Corporate Governance: An International Review', (11), pp. 189-205.

[67]. Kilic, M., Kuzey, C., \& Uyar, A. (2015) 'The impact of ownership and board structure on corporate social responsibility (CSR) reporting in the Turkish banking industry', Corporate Governance: The International Journal of Business in Society, 15(3), pp. 357-374.

[68]. Kinder, P., Domini, A. (1997) 'Social screening: Paradigms old and new', Journal of Investing, 6(4), pp. 12-19.

[69]. Kolk, A. (2008) 'Sustainability, Accountability and Corporate Governance: Exploring Multinationals' Reporting Practices', Business Strategy and the Environment, 17, pp. 1-15.

[70]. Komijani, A. and Taghizadeh-Hesary, F. (2018) 'An overview of islamic banking and finance in asia'.

[71]. Krippendorff, k. (1980) Content Analysis: An Introduction to Methodology.

[72]. Lamprinidi, S., \& Kubo, N. (2008) Debate the global reporting initiative and public agencies.

[73]. Lattemann, C., Marc Fetscherin, Ilan Alon, Shaomin Li, and Anna-Maria Schneider (2009) 'CSR communication intensity in Chinese and Indian multinational companies', Corporate Governance: An International Review 17, pp. 426-42.

[74]. Leblanc, R. and Gillies, J. (2003) ' The coming revolution in corporate governance.', Ivey Business Journal. .

[75]. Lemus, D.E. (2016) 'The Importance of CSR in Financial Reporting Standards ', Global Journal of Management and Business Research: Accounting and Auditing, 16(2).

[76]. Li, J., Pike, R. and Haniffa, R. (2008) 'Intellectual capital disclosure and corporate governance structure in UK firms', Accounting and Business Research, 38(2), pp. 137-159.

[77]. Lipton, M. and Lorsch, J.W. (1992) 'A modest proposal for improved corporate governance', Business Lawyer, 48(1), pp. 59-77.

[78]. Mahoney, J. (2004) 'Comparative - historical methodology. Annual Review of Sociology', Annual Review of Sociology, 30, pp. 81-101.

[79]. Mallin, C., Michelon, G., Raggi, D. (2013) 'Monitoring intensity and stakeholders' orientation: How does governance affect social and environmental disclosure?', Journal of Business Ethics, 114(1), pp. 29-43.

[80]. Marimon, F., Alonso-Almeida, M., \& Rodriguez, M (2012) 'The worldwide diffusion of the Global 
Reporting Initiative: What is the point?', Journal of Cleaner Production, 33, pp. 132-144.

[81]. Michelon, G., and Antonio Parbonetti (2012) 'The effect of corporate governance on sustainability disclosure', Journal of Management \& Governance, 16, pp. 477-509.

[82]. Michelon, G. and Parbonetti, A. (2012) 'The effect of corporate governance on sustainability disclosure', Journal of Management \& Governance, 16(3), pp. 477-509.

[83]. Miethe, T.D., \& Regoeczi, W. C. (2004) 'Rethinking homicide: Exploring the structure and process underlying deadly situations. New York, NY: Cambridge University Press

[84]. '.

[85]. Minelle E.Silva and D.Figueiredo, M. (2020) 'Practicing sustainability for responsible business in supply chains', Cleaner Production, 251(April 2020).

[86]. Miras-Rodríguez, M.d.M., Martínez-Martínez, D. and Escobar-Pérez, B. (2018) 'Which Corporate Governance Mechanisms Drive CSR Disclosure Practices in Emerging Countries?', Sustainability, 11(1), p. 61

[87]. Mitchell, M. (2019) A Roadmap to Sustainability: Cutting-Edge Trends in Quantifying and Reporting Success. Available at: https://www.corporatecomplianceinsights.com/sust ainability-reporting-standards/.

[88]. Muller, V.-O. (2014) 'The impact of board composition on the financial performance of FTSE100 constituents', Procedia-Social and Behavioral Sciences, 109, pp. 969-975.

[89]. Naciti, V. (2019a) 'Corporate governance and board of directors: The effect of a board composition on firm sustainability performance', Journal of Cleaner Production, 237, p. 117727.

[90]. Naciti, V. (2019b) 'Corporate governance and board of directors: The effect of a board composition on firm sustainability performance', Journal of Cleaner Production.

[91]. Nair, S. and Howlett, M. (2015) 'Scaling up of Policy Experiments and Pilots: A Qualitative Comparative Analysis and Lessons for the Water Sector', Water Resources Management, 29.

[92]. Nasrin Asgari, Ashkan Hassani, Dylan Jones and Nguyen, H.H. (2015) 'Sustainability ranking of the UK major ports: Methodology and case study', Transportation Research Part E: Logistics and Transportation Review, 78(June 2015), pp. 19-39.

[93]. Nazim Hussain, Ugo Rigoni and Orij, R.P. (2018) 'Corporate Governance and Sustainability
Performance: Analysis of Triple Bottom Line Performance', J Bus Ethics, 149, pp. 411-432.

[94]. Nicola .B, Barbara .S and P, P. (2016) 'Capturing the Stakeholders' View in Sustainability Reporting: A Novel Approach'. Research Gate.

[95]. Nielsen, S., \& Huse, M. (2010) 'The contribution of women on boards of directors: Going beyond the surface', Corporate Governance: The International Journal of Business in Society, 18(2), pp. 136-148.

[96]. Ogrizek, M. (2002) 'The effect of corporate social responsibility on the branding of financial services', Journal of Financial Services Marketing, 6(3), pp. 215-228.

[97]. Patten, D.M. (2002) 'The relation between environmental performance and environmental disclosure: a research note', Accounting, Organizations and Society, 27(8), pp. 763-773.

[98]. Peter Dobers and Halme, M. (2009) 'Corporate Social Responsibility and Developing Countries', Corporate Social Responsibility and Environmental Management, 16(5), pp. 237-249.

[99]. Petkoski, D., Twose, N. (2003) Public Policy for Corporate Social Responsibility.

[100]. Pillai, R. and Al-Malkawi, H.-A.N. (2018) 'On the relationship between corporate governance and firm performance: Evidence from GCC countries', Research in International Business and Finance, 44, pp. 394-410.

[101]. Porter, M.E., Kramer, M.R. (2006) 'Strategy \& society: The link between competitive advantage and corporate social responsibility', Harvard Business Review, 84(12), pp. 78-92.

[102]. Ragin, C.C. (1987) The comparative method: Moving beyond qualitative and quantitative Strategies Berkeley, CA: University of California Press.

[103]. Ragin, C.C. (2018) 'User's Guide to Fuzzy-Set/Qualitative Comparative Analysis 3.0', Irvine, California: Department of Sociology, University of California.

[104]. Ragin, C.C., Mayer, S. E., \& Drass, K. A. (1984) 'Assessing discrimination: A Boolean approach', American Sociological Review, 49(2), pp. 221-234.

[105]. Ragin, C.C.F., P. C. (2008) 'Net effects analysis versus configurational analysis: An empirical demonstration' Ragin, C.C. Fuzzy sets and beyond. University of Chicago Press, pp. 190-212.

[106]. Rekha Pillai and Al-Malkawi, H.-A.N. (2017) 'On the relationship between corporate governance and firm performance: Evidence from GCC countries', International Business and Finance. 
[107]. Rihoux, B., \& Ragin, C. C. (Eds.). (2009) 'Configuration comparative methods: Qualitative Comparative Analysis (QCA) and related techniques', Thousand Oaks, CA: Sage Publications.

[108]. Rose, C. (2007) 'Does female board representation influence firm performance? The Danish evidence', Corporate Governance: An International Review 15, pp. 404-413.

[109]. Rose, S., Hair, N. and Clark, M. (2011) 'Online Customer Experience: A Review of the Business-to-Consumer Online Purchase Context', International Journal of Management Reviews, 13(1), pp. 24-39.

[110]. Rosenstein, S., and Jeffrey G. Wyatt. (1990) 'Outside directors, board independence, and shareholder wealth', Journal of Financial Economics, 26, pp. 175-91.

[111]. Sahay.A (2004) 'Environmental reporting by Indian corporations' 24 Febrauary 2004. Wiley Online Library: Corp. Soc. Responsibility. Environment.Manager 11 (1), pp. 12-22.

[112]. Said, R., Yuserrie Hj Zainuddin, and Hasnah Haron (2009) 'The relationship between corporate social responsibility disclosure and corporate governance characteristics in Malaysian public listed companies', Social Responsibility Journal 5, pp. 212-26.

[113]. Sangmi, M.-u.-d. and Khaki, A.R. (2018) Islamic Banking: Concept and Methodology '.

[114]. Schneider, M., Schulze-Bentrop, C., Paunescu, M. (2010) 'Mapping the institutional capital of high-tech firms: A fuzzy-set analysis of capitalist variety and export performance', Journal of International Business Studies, 41, pp. 246-266.

[115]. Snow, L. (2019) The top trend in CSR reporting in 2019. Available at: https://www.conecomm.com/insights-blog/2019/1 0/10/the-top-ten-trends-in-csr-reporting-in-2019.

[116]. ThomasBorgert, Jerome D.Donovan, ChereeTopple and K.Masli, E. (2020) 'Impact analysis in the assessment of corporate sustainability by foreign multinationals operating in emerging markets: Evidence from manufacturing in Indonesia', Cleaner Production, 260(1 July 2020).

[117]. Tschopp, D.J. (2005) 'Corporate Social Responsibility: A Comparison between the United States and the European Union. Corporate Social

[118]. Responsibility and Environment Management' 2005. Wiley online library: Corporate Social

[119]. Responsibility and Environment Management .I2, pp. 55-59.
[120]. UKEssays (2018) Corporate Social Responsibility And Stakeholder Theory. Available at:

https://www.ukessays.com/essays/management/lin k-between-corporate-responsibility-and-stakeholde r-theory-management-essay.php?vref=1.

[121]. VBCFSD (2014) Current usage and trends of sustainability reporting in Vietnam and worldwide. Vietnam business council for sustainable development.

[122]. Walls, J.L., Berrone, P. and \& Phan, P.H. (2012) 'Corporate governance and environmental performance: Is there really a link?', Strategic Management Journal, 33(8), pp. 885-913.

[123]. Yusoff.S, Yulisa.H and L, G. (2007) 'Environmental reporting in a developing country: a case study on status and implementation in Malaysia', Malaysian accounting review, 11(Special issue).

[124]. Zelechowski, D.D., Bilimoria, D. (2004) 'Characteristics of women and men corporate inside directors in the US', Corporate Governance: An International Review, 12, pp. 337-342.

[125]. Zhang, J.Q., Zhu, H., Ding, H.-B. (2013) 'Board composition and corporate social re-sponsibility: an empirical investigation in the post sarbanes-oxley era', J. Bus.Ethics, 114(3), pp. 381-392. 